\title{
ON THE GEOELECTRICAL DIFFERENCE BETWEEN THE KURIL-KAMCHATKA AND Bering SEA SEgMENTS OF THE PACIFIC TRANSITION ZONE
}

\author{
Yu. F. Moroz ${ }^{1,2}$, 0. M. Samoilova1 \\ ${ }^{1}$ Institute of Volcanology and Seismology, Far East Branch of RAS, Petropavlovsk-Kamchatsky, Russia \\ ${ }_{2}^{2}$ Geological Institute, Siberian Branch of RAS, Ulan-Ude, Russia
}

\begin{abstract}
The data from the regional magnetotelluric sounding profiles Severny and Yuzhny (northern and southern, respectively) was analyzed and interpreted. The profiles were located on several sites of the eastern coast of Kamchatka, which differ in tectonic structure and geodynamic conditions. The southeastern region covers the KurilKamchatka segment of the Pacific transition zone, which corresponds to the active continental margin, while the northeastern region includes the passive continental margin. Geoelectrical sections were obtained along the regional profiles to a depth of about $80 \mathrm{~km}$. The identified anomalies of electrical conductivity were compared with the data obtained by other geophysical methods (specifically, the data on gravity and anomalous magnetic fields). The comparative analysis of the geoelectrical sections shows that electrical conductivity changes gradually in the northeastern region, while the structure of the southeastern region is represented by blocks differing in geoelectrical properties. The conducting horizon of the lithosphere lies at different depths in different parts of East Kamchatka. The southeastern section shows the roof of the lithospheric layer closest to the land surface.
\end{abstract}

Key words: magnetotelluric sounding; regional profile; deep geoelectrical model; lithospheric conductive layer; Pacific transition zone; numerical simulation

\section{RESEARCH ARTICLE}

Received: February 19, 2018

Handling Editor: K.Zh. Seminsky

For citation: Moroz Yu.F., Samoilova O.M., 2018. On the geoelectrical difference between the Kuril-Kamchatka and Bering Sea segments of the Pacific transition zone. Geodynamics \& Tectonophysics 9 (2), 489-501. doi:10.5800/GT-2018-9-2-0357.

Для цитирования: Мороз Ю.Ф., Самойлова О.М. О геоэлектрическом различии курило-камчатского и беринговоморского сегментов Тихоокеанской зоны перехода // Геодинамика и тектонофизика. 2018. T. 9. № 2. C. 489-501. doi:10.5800/GT-2018-9-2-0357. 


\title{
О ГЕОЭЛЕКТРИЧЕСКОМ РАЗЛИЧИИ КУРИЛО-КАМЧАТСКОГО И БЕРИНГОВОМОРСКОГО СЕГМЕНТОВ ТИХООКЕАНСКОЙ ЗОНЫ ПЕРЕХОДА
}

\author{
Ю. Ф. Мороз ${ }^{1,2}$, О. М. Самойлова 1 \\ ${ }^{1}$ Институт вулканологии и сейсмологии ДВО РАН, Петропавловск-Камчатский, Россия \\ ${ }^{2}$ Геологический институт СО РАН, Улан-Удэ, Россия
}

\begin{abstract}
Аннотация: Рассмотрены результаты интерпретации данных магнитотеллурического зондирования, полученных по региональным профилям «Северный» и «Южный». Профили расположены в разных районах восточного побережья Камчатки, отличающихся по тектоническому строению и геодинамической обстановке. Юго-восточный район исследования входит в пределы курило-камчатского сегмента Тихоокеанской зоны перехода, соответствующего активной континентальной окраине. Северо-восточный район исследований, напротив, находится на территории пассивной окраины континента. Геоэлектрические разрезы получены вдоль региональных профилей до глубины порядка 80 км. Выделенные аномалии электропроводности сопоставляются с данными других геофизических методов (с данными поля силы тяжести и аномального магнитного поля). Сравнительный анализ геоэлектрических разрезов показывает, что на северо-восточном побережье региона происходит плавное изменение электропроводности, в юго-восточной части геоэлектрическое строение носит блочный характер. Литосферный проводящий горизонт в разных районах Восточной Камчатки залегает на разных глубинах, и максимальное приближение кровли слоя к поверхности наблюдается в юго-восточном разрезе.
\end{abstract}

Ключевые слова: магнитотеллурическое зондирование; региональный профиль; глубинная геоэлектрическая модель; литосферный проводящий слой; Тихоокеанская зона перехода; численное моделирование

\section{1. ВВЕДЕНИЕ}

В рамках долговременной программы комплексных геофизических исследований, проводимой организацией ОАО «Камчатгеология» на территории Камчатки, в 2009 г. были выполнены магнитотеллурические зондирования (МТЗ) по двум региональным профилям, расположенным на юговосточном (профиль «Южный») и северо-восточном (профиль «Северный») побережьях региона (рис. 1). Первый из них находится в пределах Курило-Южно-Камчатской структурно-формационной зоны. Профиль «Северный» начинается в ВосточноКамчатской зоне, продолжается в Центрально-Камчатской и Олюторской структурно-формационных зонах. Однако, как показывает анализ работ предшественников [Belousov, 1987; Seliverstov, 1998, 2009], исследуемые районы относятся также и к разным геодинамическим обстановкам. Восточная часть региона от мыса Лопатка до п-ова Камчатский, расположенная на границе с Тихим океаном, а также прилегающий участок Курило-Камчатского глубоководного желоба относятся к активной континентальной окраине. В работе [Seliverstov, 1998] показано, что под Камчатку погружается латерально неоднородная по плотности литосфера. Часть Восточной Камчатки, граничащей с Беринговым морем, соответствует пассивной окраине континента [Seliverstov, 1998, 2009]. Согласно существующим представлениям, в этой части региона происходит взаимодействие литосферных плит разного типа: во-первых, обдукции субокеанической плиты [Mishin et al., 2003] на краевую часть материковой плиты в северо-западном направлении и, во-вторых, субдукции со стороны Пенжинского рифта в юго-западном направлении [Nurmukhamedov, Moroz, 2008, 2009]. Это предполагает, что беринговоморский сегмент Тихоокеанской зоны перехода, к которому относится северо-восток Камчатки, имеет отличное от курило-камчатского сегмента строение.

Таким образом, одновременное изучение особенностей глубинного строения как островной части Восточной Камчатки с характерными для активной континентальной окраины действующими вулканами, высокой сейсмичностью и гидротермальной активностью, так и материковой части, выступающей в роли пассивной окраины конти- 


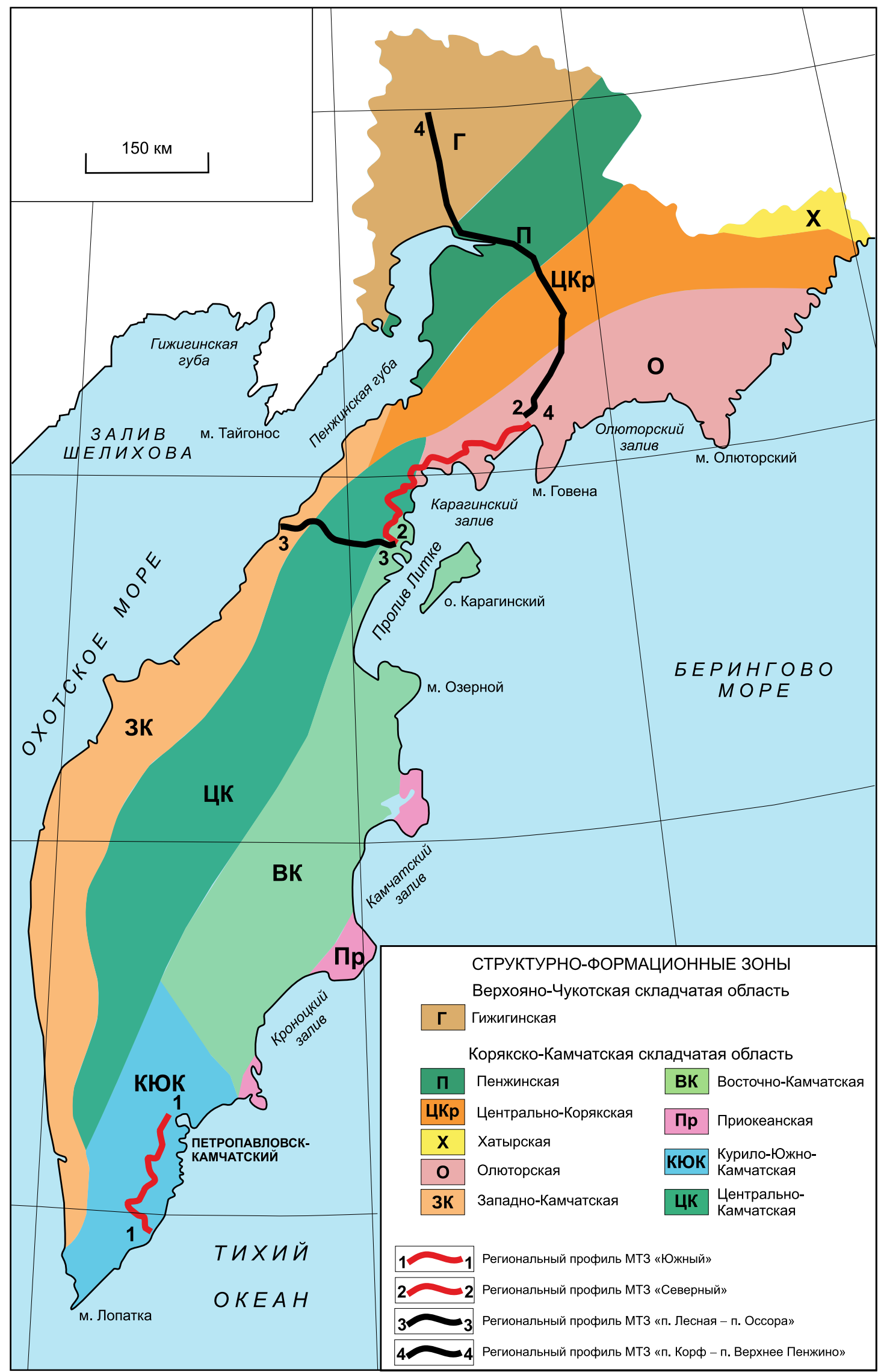

Pис. 1. Схема структурно-формационного районирования Корякско-Камчатской складчатой области [Litvinov et al., 1999] с расположением региональных профилей МТЗ «Южный» и «Северный».

Fig. 1. Schematic map showing structure-formation zoning of the Koryak-Kamchatka folded region [Litvinov et al., 1999] and the locations of the regional MTS profiles Yuzhny and Severny. 
Yu.F. Moroz, O.M. Samoilova: On the geoelectrical difference between the Kuril-Kamchatka and Bering Sea segments...

нента, является важным для решения вопросов тектоники и геологии. Также в пределах обоих районов восточного побережья Камчатки обнаружен ряд проявлений полезных ископаемых, что представляет значительный интерес для геологовпрактиков.

В настоящей работе изучение особенностей глубинного строения разных районов Восточной Камчатки основано на данных МТЗ, полученных вдоль региональных профилей «Северный» и «Южный», и сопоставлении выделенных аномалий электропроводности с данными других геофизических методов. Методика полевых исследований и интерпретации материалов МТЗ подробно изложена в работах [Moroz, Samoilova, 2013, 2017; Moroz et al., 2015]. Здесь авторы предлагают сопоставление и сравнительный анализ глубинных геоэлектрических разрезов разных по тектоническому строению и геодинамической обстановке участков восточного побережья региона.

\section{2. ГЕОЛОГО-ГЕОФИЗИЧЕСКАЯ ИЗУЧЕННОСТЬ РАЙОНОВ ИССЛЕДОВАНИЯ}

Исследуемые профили находятся на восточном побережье Камчатки, которое, как и остальная часть региона, во второй половине прошлого века было изучено гравиметрической и аэромагнитной съемкой масштаба 1:200000.

Район профиля «Северный» характеризуется относительно пониженным уровнем гравитационного поля [Seliverstov, 1998]. Повышенные значения поля силы тяжести отвечают Ильпинскому поднятию. В пределах Кичигинского залива выделяется крупный и относительно интенсивный минимум северо-восточного простирания, связанный с Кичигинской впадиной. Аномальное магнитное поле, в свою очередь, имеет ярко выраженный полосовой характер. Так, в районе Вывенской, Анапкинской и Кичигинской впадин, северной части Ильпинского поднятия, аномальное магнитное поле принимает отрицательные значения. Тымлатскому поднятию и южной части Ильпинского поднятия отвечают положительные значения аномального магнитного поля [Rivosh, 1964].

Аномальное магнитное поле в районе Юго-Восточной Камчатки имеет полосовой характер, отражающий зональное распределение главных тектонических элементов. Областям вулканических построек (вулканы Горелый, Асача, Ходутка, Мутновский) соответствуют положительные аномалии магнитного поля. Данные аномалии отражают наличие в разрезе вулканогенных магматических образований. Западная часть Южно-Камчатского антиклинория характеризуется отрицательным маг- нитным полем. В сторону Тихого океана происходит возрастание напряженности магнитного поля, что связано с приближением к дневной поверхности намагниченных пород [Rivosh, 1963]. В целом по направлению к Тихому океану также происходит закономерное возрастание интенсивности поля силы тяжести. Стоит отметить, что в пределах юговосточного района исследований выделяется система разломов, продольных и поперечных по отношению к простиранию структурных элементов первого порядка. Такие разломы накладываются на линейно-складчатую структуру Камчатки, формируя складчато-блоковое строение [Sobolev, 1979].

Что касается исследований методами электроразведки, то в большинстве случаев они выполнялись на удалении от восточного побережья. На юговостоке Камчатки в 2004-2006 гг. были проведены локальные МТЗ для изучения геоэлектрического разреза Мутновского месторождения парогидротерм до небольших глубин (около 8 км) [Nurmukhamedov et al., 2010]. Позже на основании данных нескольких региональных профилей, пересекающих южную часть региона с запада на восток, была получена трехмерная геоэлектрическая модель [Belyavksii, Aleksanova, 2014], в которой не учтен береговой эффект, возникающий на границе высокоомной суши и хорошо проводящего электрический ток океана и в высокой степени искажающий экспериментальные данные. Таким образом, удельное электрическое сопротивление в полученной модели имеет завышенные значения. В северной части Камчатки также проводились работы методом МТ3 по профилям, имеющим направление от восточного побережья в центр и на запад региона. Так был получен геоэлектрический разрез вдоль регионального профиля от поселка Лесная до поселка Ocсора, пересекающего Камчатский перешеек в центральной части [Nurmukhamedov, 2003; Mishin et al., 2003]. На севере материковой части Камчатки получен геоэлектрический разрез по профилю, протягивающемуся от поселка Корф до поселка Верхнее Пенжино и пересекающему Олюторскую, Центрально-Корякскую, Пенжинскую и Гижигинскую структурно-формационные зоны, границы которых продемонстрированы на рис. 1 [Belyavksii et al., 2008].

Несмотря на большой объем геологической и геофизической информации, на сегодняшний день не существует общепринятой тектонической схемы Камчатки, отражающей особенности ее геологического строения. Вопросам тектоники южной части Камчатки, включая ее восточное побережье, посвящено множество работ. Существует ряд положений, с которыми согласно большинство исследователей тектоники этой части региона. Во-первых, Камчатка делится на две крупные тектонические 


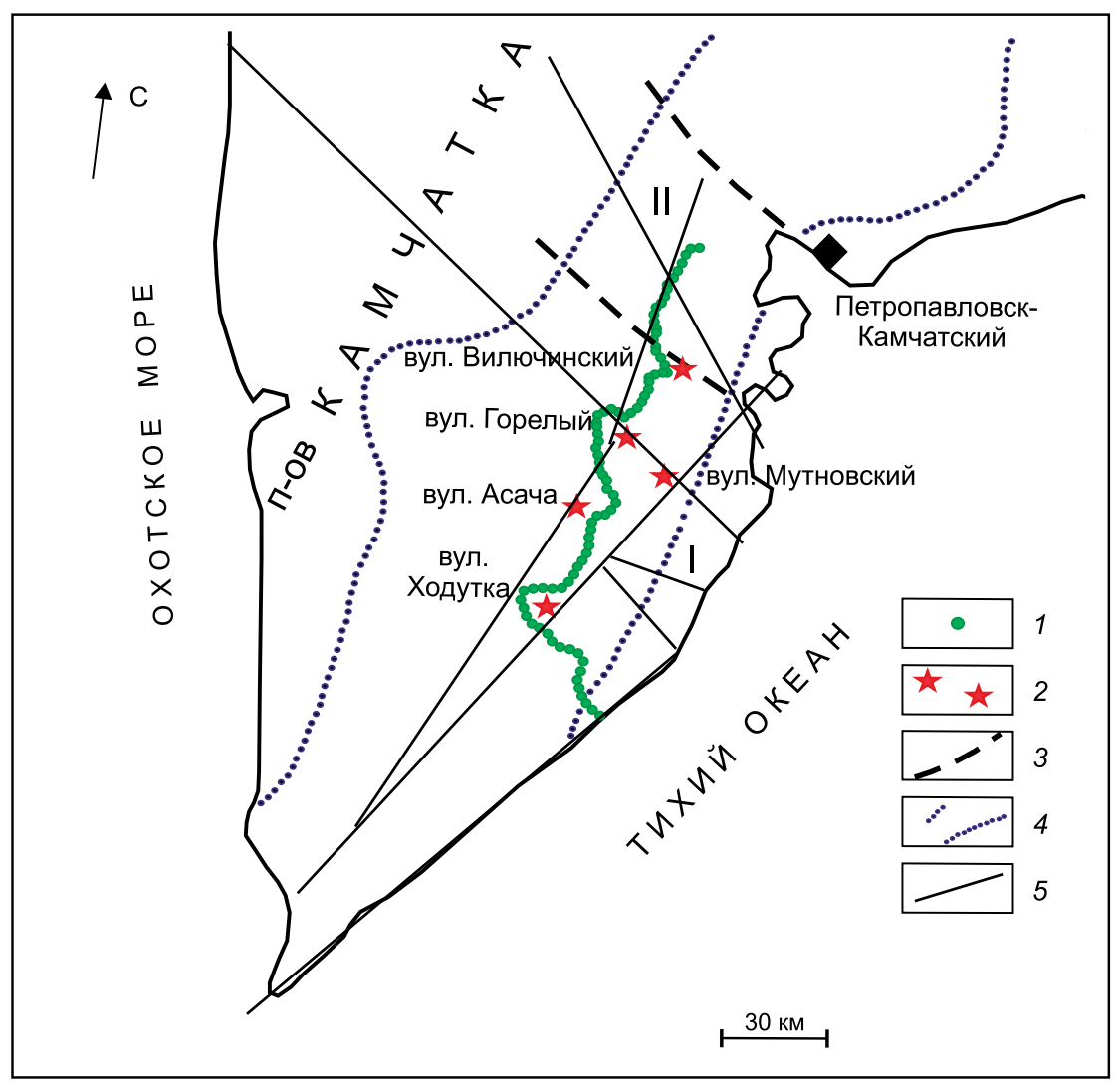

Рис. 2. Схема расположения профиля МТЗ «Южный» [Moroz, Samoilova, 2013].

1 - пункты МТ3; 2 - вулканы; 3 - граница поперечной структуры [Geology of the USSR, 1964; Aprelkov, 1971]; 4 - границы вулканического пояса [Geology of the USSR, 1964]; 5 - разрывные нарушения [Seliverstov, 2013]. I - Южно-Камчатский антиклинорий, II Начикинская зона поперечных дислокаций.

Fig. 2. Schematic map showing the location of the MTS profile Yuzhny [Moroz, Samoilova, 2013].

1 - MTS points; 2 - volcanoes; 3 - boundary of the transverse structure [Geology of the USSR, 1964; Aprelkov, 1971]; 4 - boundaries of the volcanic belt [Geology of the USSR, 1964]; 5 - ruptures [Seliverstov, 2013]. I - South Kamchatka anticlinorium, II - Nachikin zone of transverse dislocations.

области - западную с платформенным строением и восточную с наличием зоны субдукции, подробно описанным в работах [Krasny, 1966; Smirnov, 1971, Seliverstov, 2009]. Во-вторых, выходы древних протерозойских пород и сопряженных с ними структурных элементов являются секущими по отношению к северо-восточному простиранию структур Камчатки. Так, выходы метаморфизованных пород в районе Ганальского выступа имеют северо-западное направление и продолжаются в простирании Начикинской зоны поперечных дислокаций [Geology of the USSR, 1964; Aprelkov, Podpruzhenko, 2009], которую пересекает региональный профиль «Южный» (рис. 2).

Еще одна крупная структура, в пределах которой находится профиль «Южный», - Южно-Камчатский антиклинорий (рис. 2). Значительную информацию о строении Южной Камчатки дают результаты глубинного сейсмического зондирования (ГСЗ), согласно которым часть полуострова, распо- ложенную южнее г. Петропавловска-Камчатского, следует рассматривать как область уменьшения мощности земной коры. В районе антиклинория она достигает 24 км, что почти на 10-12 км меньше, чем в более северных районах. Осевая часть антиклинория совпадает с береговой границей, а его юго-восточное крыло погружено под воду [Vlasov, Yarmolyuk, 1959].

Наряду с рассматриваемыми крупными структурами южного района здесь выделяется ВосточноКамчатский вулканический пояс с современными действующими и потенциально активными вулканами. Так, несколько пунктов МТЗ профиля «Южный» располагаются вблизи вулканов Горелый, Мутновский и Ходутка. По данным сейсмической томографии [Gontovaya et al., 2010] установлено, что земная кора содержит аномалии, в пределах которых отмечается понижение сейсмической скорости на 4-6 \% относительно фоновых значений сейсмических скоростей. 


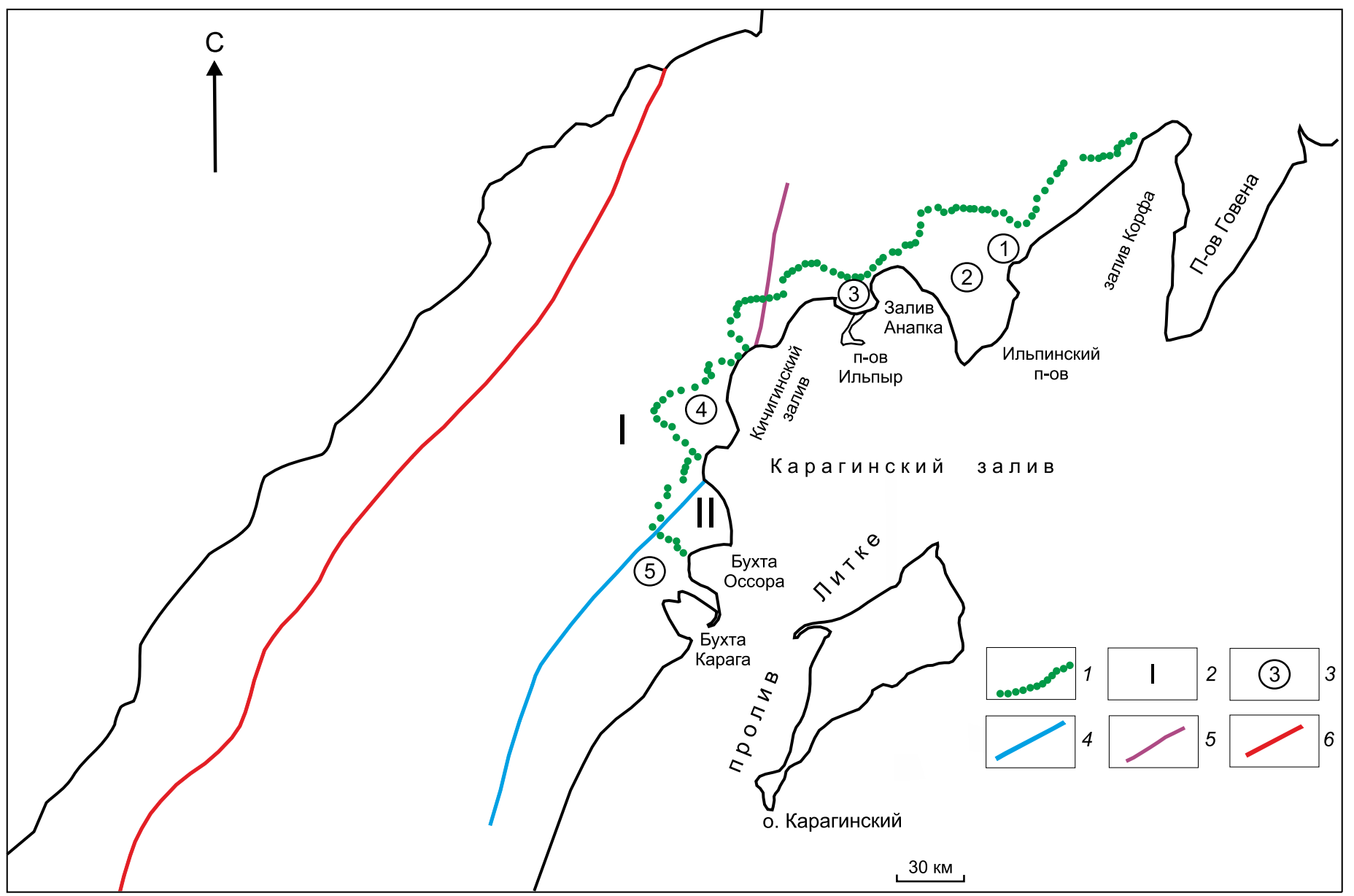

Рис. 3. Схема расположения профиля МТЗ «Северный».

1 - пункты МТ3; 2 - структурные элементы первого порядка [Geology of the USSR, 1964]: I - Лесновско-Ватынский антиклинорий, II - Ильпино-Литкенский прогиб; 3 - структурные элементы второго порядка [Geology of the USSR, 1964]: 1 - Вывенская впадина, 2 - Ильпинское поднятие, 3 - Анапкинская впадина, 4 - Кичигинская впадина, 5 - Тымлатское поднятие; 4-5 - тектонические границы структурно-формационных зон, соответствующие глубинным разломам, выделенные: 4 - по геологическим данным, 5 - по геофизическим данным; 6 - тектонические границы структурно-формационных подзон и прочих разнородных блоков [Litvinov et al., 1999].

Fig. 3. Schematic map showing the location of the MTS profile Severny.

1 - MTS points; 2 - first-order structural elements [Geology of the USSR, 1964]: I - Lesnov-Vatynsky anticlinorium, II - Ilpino-Litkensky trough; 3 - second-order structural elements [Geology of the USSR, 1964]: 1 - Vyvenskay depression, 2 - Ilpinsky uplift, 3 - Anapkin depression, 4 - Kichigin depression, 5 - Tymlat uplift; 4-5 - the tectonic boundaries of the structure-formation zones, which correspond to deep faults, identified from the geological (4) and geophysical data (5); 6 - tectonic boundaries of structure-formation subzones and various other blocks [Litvinov et al., 1999].

В тектоническом плане район северо-восточного побережья расположен в Ильпино-Литкенском прогибе, являющемся продолжением Центрально-Камчатского прогиба. На северо-западе Ильпино-Литкенский прогиб граничит с Камчатско-Корякским антиклинорием, который представляет собой крупную пологую антиклинальную структуру, по форме близкую сводовому поднятию. На юго-востоке Ильпино-Литкенский прогиб ограничен Восточно-Камчатским антиклинорием, прослеживающимся на п-ове Озерном, п-ове Карагинском и п-ове Говена [Geology of the USSR, 1964].
Наиболее приподнятая часть прогиба расположена на п-ове Ильпинском (Ильпинское поднятие), а наиболее погруженные части совпадают с границами Вывенской и Кичигинской впадин. Вывенская впадина охватывает северо-восточную часть Ильпинского полуострова и выполнена преимущественно терригенными палеоген-неогеновыми отложениями. Большая часть Кичигинской впадины находится под водами пролива Литке. С юга к Кичигинской впадине примыкает Тымлатское поднятие, которое в основном скрыто водами Берингова моря (рис. 3). 


\section{3. МЕТОДИКА ТРЕХМЕРНОГО МОДЕЛИРОВАНИЯ}

С учетом результатов двумерной инверсии по региональным профилям «Северный» и «Южный» [Moroz, Samoilova, 2017], батиметрических данных [Seliverstov, 2009], а также другой геолого-геофизической информации о строении рассматриваемых районов была построена трехмерная геоэлектрическая модель. Система координат модели согласована с системой наблюдений, в которой азимут оси $\mathrm{X}$ составляет $120^{\circ}$, оси Y - $30^{\circ}$. Область моделирования покрыла территорию порядка $1380 \times 2240$ км при размерах пространственной прямоугольной сетки $60 \times 150 \times 30$ ячеек. На суше размер ячеек по горизонтальным осям менялся от 7.5 до 15 км, а по мере удаления в акваторию Охотского моря и Тихого океана - от 15 до 200 км. Глубина разреза составила $10^{3}$ км при достаточно подробном разделении на слои верхней части. До отметки 10 км мощность слоев менялась от 0.1 до 2.0 км. Далее до глубин 120 км размер ячеек варьировался от 10 до 20 км. Ниже этой отметки вертикальный размер блоков увеличивался от 50 до 400 км.

Фоновый геоэлектрический разрез, окружающий рабочую область модели, является двумерным. В верхней части до глубин 7 км находится низкоомный слой с удельным электрическим сопротивлением 0.25 Ом·м. Он имитирует водную толщу Тихого океана, Охотского и Берингова морей. Водный слой перекрывает однородный высокоомный горизонт (удельное электрическое сопротивление 1000 Ом·м) мощностью 80 км. Ниже отметки глубины 87 км значения удельного электрического сопротивления понижаются и высокоомный горизонт подстилается низкоомными слоями мощностью от 120 до 400 км и удельным электрическим сопротивлением, меняющимся в пределах от 100 до 10 Ом•м. Это «нормальный» глубинный геоэлектрический разрез, параметры которого взяты из работы [Van'yan, 1977].

Расчеты проводились в программе MT3 DFwd [Mackie et al., 1994] в диапазоне периодов от 0.1 до 10000 с. Для минимизации расхождения модельных и экспериментальных параметров модель корректировалась в ручном режиме. В целом, результаты расчетов достаточно хорошо согласуются с экспериментальными данными в широком диапазоне периодов. В лучшей мере соответствие достигнуто для продольных кривых МТЗ, полученных вдоль простирания Камчатки по региональным профилям «Северный» и «Южный». В этом случае расхождение модельных и экспериментальных параметров не превышает 5 \%. Для поперечных кривых соответствие ухудшается на периодах свыше 10 с и расхождение расчетных и наблюденных значений достигает $15 \%$. В блоках моделирования 1-4 по профилю «Северный» не удалось добиться хорошей сходимости модельных и экспериментальных поперечных кривых, что обусловлено действием трехмерных эффектов в районе исследований. В этих блоках кривые МТЗ подобны по форме, но экспериментальные кривые находятся выше модельных по уровню кажущегося удельного сопротивления во всем диапазоне периодов.

\section{4. ГЕОЭЛЕКТРИЧЕСКИЕ РАЗРЕЗЫ ВОСТОЧНОГО ПОБЕРЕЖЬЯ ЮЖНОЙ И СЕВЕРНОЙ КАМЧАТКИ}

Результаты трехмерного моделирования для района юго-восточного побережья Камчатки представлены на рисунке 4. В северо-восточной части профиля «Южный» до вулкана Вилючинский удельное электрическое сопротивление до глубины 2 км принимает значение $300 \mathrm{Oм}$ •м и возрастает до 3000 Ом·м при достижении глубины 20-30 км. Увеличение данного параметра, скорее всего, связано с присутствием в разрезе высокоомных магматических пород.

Под вулканом Мутновский на глубине от 1 до 2 км выделена низкоомная аномалия со значением удельного электрического сопротивления 50 Ом·м, которая также была выделена другими авторами при построении трехмерной геоэлектрической модели Мутновского месторождения парогидротерм [Nurmukhamedov et al., 2010]. Вероятно, наличие низкоомной аномалии связано с зоной тектонического нарушения, которая отражена на Карте [Litvinov et al., 1999] и которая может выступать в качестве резервуара, содержащего минерализованные растворы. От отметки 2 км начинается субвертикальная высокоомная аномалия до глубины порядка 60 км с удельным электрическим сопротивлением, лежащим в пределах от 1000 до 10000 Ом•м. К высокоомной аномалии также приурочен вулкан Асача. Предполагается, что ее природа может быть связана с насыщенностью разреза высокоомными магматическими породами, которые находят отражение в виде аномалий повышенной интенсивности гравитационного поля и возмущенного аномального магнитного поля.

Выделенная область повышенного удельного электрического сопротивления разделяет разрез под вулканами Горелый и Ходутка, под которыми до глубины 5 км данный параметр не превышает 150 Ом·м, а в интервале глубин от 5 до $30 \mathrm{\kappa м} \mathrm{он}$ принимает значение порядка 50 Ом·м. Выделенная проводящая зона может быть связана с наличием в разрезе магматических расплавов и гидротермальных растворов. Стоит отметить, что ранее по данным сейсмической томографии под вулканом Горелый была выделена зона пониженной сейсмиче- 

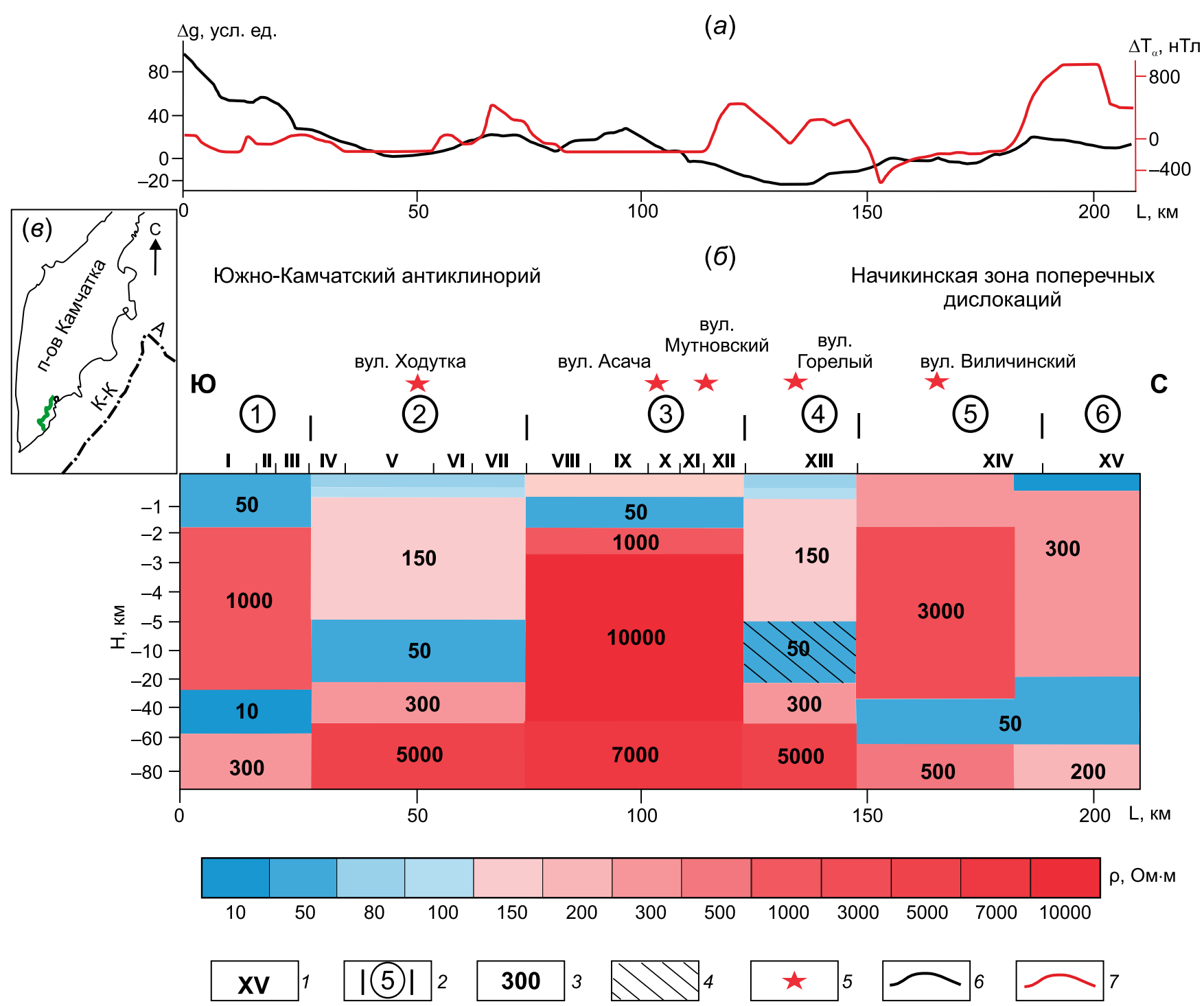

Рис. 4. Глубинный геоэлектрический разрез вдоль регионального профиля «Южный», (б), приведенный в сопоставлении с графиками аномального магнитного поля и поля силы тяжести $(a)$.

1 - зоны, выделенные на первом этапе конформного осреднения кривых МТ3; 2 - блоки, выделенные на втором этапе конформного осреднения кривых МТ3; 3 - значения удельного электрического сопротивления в Ом•м; 4 - область пониженных сейсмических скоростей [Gontovaya et al., 2010]; 5 - вулканы [Litvinov et al., 1999]; 6 - график поля силы тяжести [Декин, 3убин, 1976]; 7 график аномального магнитного поля [Rivosh, 1963]. На вставке (в) зеленой линией показано расположение регионального профиля «Южный», черной линией показано положение осей глубоководных желобов (К-К - Курило-Камчатский, А - Алеутский) [Seliverstov, 2009].

Fig. 4. Deep geoelectrical section along the regional profile Yuzhny (б), given in comparison with the magnetic anomaly and gravity curves $(a)$.

1 - zones identified at the first stage of conformal averaging of the MTS curves; 2 - blocks identified at the second stage of conformal averaging of the MTS curves; 3 - values of specific electrical resistance $(\mathrm{Ohm} \cdot \mathrm{m}) ; 4$ - region of low seismic velocities [Gontovaya et al., 2010]; 5 - volcanoes [Litvinov et al., 1999]; 6 - gravity curve [Dekin, Zubin, 1976]; 7 - magnetic anomaly curve [Rivosh, 1963]. Inset (8): green line - regional profile Yuzhny, black line - axes of deep-sea troughs (K-K - Kuril-Kamchatka, A - Aleutian) [Seliverstov, 2009].

ской скорости [Gontovaya et al., 2010], с которой согласуется выделенная в настоящем исследовании низкоомная аномалия. Область пониженного удельного электрического сопротивления также отражена в пониженной интенсивности поля силы тяжести. Возмущенный характер магнитного поля над выделенной областью объясняется присут- ствием в верхней части разреза вулканогенных пород. Низкоомная аномалия под вулканом Ходутка может быть связана с глубинным разломом, насыщенным магматическими расплавами. Ей соответствует относительно низкий уровень поля силы тяжести и возмущенный характер магнитного поля. 
В юго-восточном сегменте профиля «Южный» верхняя часть разреза земной коры до 2 км выражается слоем низкого удельного электрического сопротивления в 50 Ом·м. Эта аномалия перекрывает высокоомный слой (1000 Ом·м) мощностью 28 км, ниже которого в интервале глубин от 30 до 60 км залегает слой с удельным электрическим сопротивлением около 10 Ом·м. В поле силы тяжести этой аномалии отвечают локальные возмущения на фоне региональной аномалии, связанной с увеличением плотности и уменьшением мощности земной коры при переходе от континента к океану. В магнитном поле здесь также выражены локальные аномалии, связанные с насыщенностью разреза магматическими образованиями.

Обратимся к результатам трехмерного моделирования в районе северо-восточного побережья Камчатки (рис. 5). Как и в предыдущем случае, разрез сопоставлен с графиками геофизических полей. Геоэлектрический разрез характеризуется изменением удельного электрического сопротивления в широких пределах - от первых единиц до 5000 Ом·м в юго-восточной части исследуемого района и плавным изменением этого параметра в северо-восточной части. Здесь удельное электрическое сопротивление принимает значения от 10 до 100 Ом·м.

В районе Тымлатского поднятия и ЛесновскоВатынского антиклинория выделена высокоомная аномалия (1000-5000 Ом•м) в интервале глубин от 1 до 40 км в зонах I и III и от 1 до 10 км в зоне II. В верхней части разреза Тымлатское поднятие характеризуется преимущественно увеличенным удельным электрическим сопротивлением кайнозойской толщи, составляющим 50-70 Ом•м. В пределах Лесновско-Ватынского антиклинория до глубины около 1 км удельное электрическое сопротивление достигает порядка 300 Ом·м. Повидимому, это связано с присутствием в разрезе вулканогенных образований. На это указывает повышенная интенсивность отрицательного магнитного поля и повышенная напряженность гравитационного поля, а также интрузии четвертичного и неогенового возраста, закартированные геологической съемкой на дневной поверхности.

Кичигинская и Анапкинская впадины характеризуются повышенной электропроводностью осадочно-вулканогенного чехла, в разрезе которого преобладают терригенные породы с удельным электрическим сопротивлением порядка 10 Ом·м. Мощность низкоомной толщи кайнозойских отложений составляет 1 км.

Вывенская впадина также сложена кайнозойскими породами с удельным электрическим сопротивлением 10-50 Ом·м. Повышенная проводимость осадочного чехла впадины обусловлена преобла- данием в разрезе терригенных пород, имеющих повышенную пористость и насыщенных минерализованными водами. Впадина отличается спокойным поведением гравитационного, магнитного и теллурического полей. Отрицательный уровень магнитного поля впадины свидетельствует о наличии в верхней части разреза вулканогенных образований.

В литосфере выделен слой с удельным электрическим сопротивлением 5-15 Ом·м, мощность которого достигает 30 км в пределах всего района исследований. Примечательно то, что в зоне II, pacположенной в пределах Лесновско-Ватынского антиклинория, кровля низкоомного слоя находится на глубине 10 км. В юго-западном направлении, под Тымлатским поднятием, а также на границе Лесновско-Ватынского антиклинория и Кичигинской впадины глубина кровли выделенного слоя погружается до 35 км. Ниже корового проводящего горизонта геоэлектрический разрез в целом является низкоомным. Стоит отметить, что полученный результат согласуется с ранее полученным геоэлектрическим разрезом вдоль профиля, пересекающего Камчатский перешеек от поселка Лесная до поселка Оссора [Nurmukhamedov, 2003].

\section{5. ОБСУЖДЕНИЕ РЕЗУЛЬТАТОВ}

В результате настоящего исследования получены глубинные геоэлектрические разрезы (до 80 км) в пределах курило-камчатского и беринговоморского сегментов Тихоокеанской зоны перехода. В обоих районах выделен литосферный слой низкого удельного электрического сопротивления. Понижение параметра сопротивления до первых единиц-десятков Ом•м может быть обусловлено флюидами или электронной проводимостью. Однако стоит отметить, что присутствие в разрезе рудных минералов, осуществляющих электронную проводимость, может приводить к образованию жильных тел, размеры которых будут гораздо меньше, чем размеры горизонтов, выделенных в разрезе восточного побережья Северной и Южной Камчатки. Именно поэтому мы связываем пониженное удельное электрическое сопротивление с проводящими флюидами. Высокая флюидная насыщенность может быть объяснена высокой пористостью и проницаемостью пород, которые, в свою очередь, являются результатом тектонических движений. В результате подвига океанической плиты под континентальную, который происходит в районе Юго-Восточной Камчатки, в самой верхней части литосферы (первые 8-10 км) могут образовываться магистральные разрывы (раздвиги), на более значительных глубинах сменяющиеся 
$\Delta \mathrm{g}$, усл. ед.

(a)
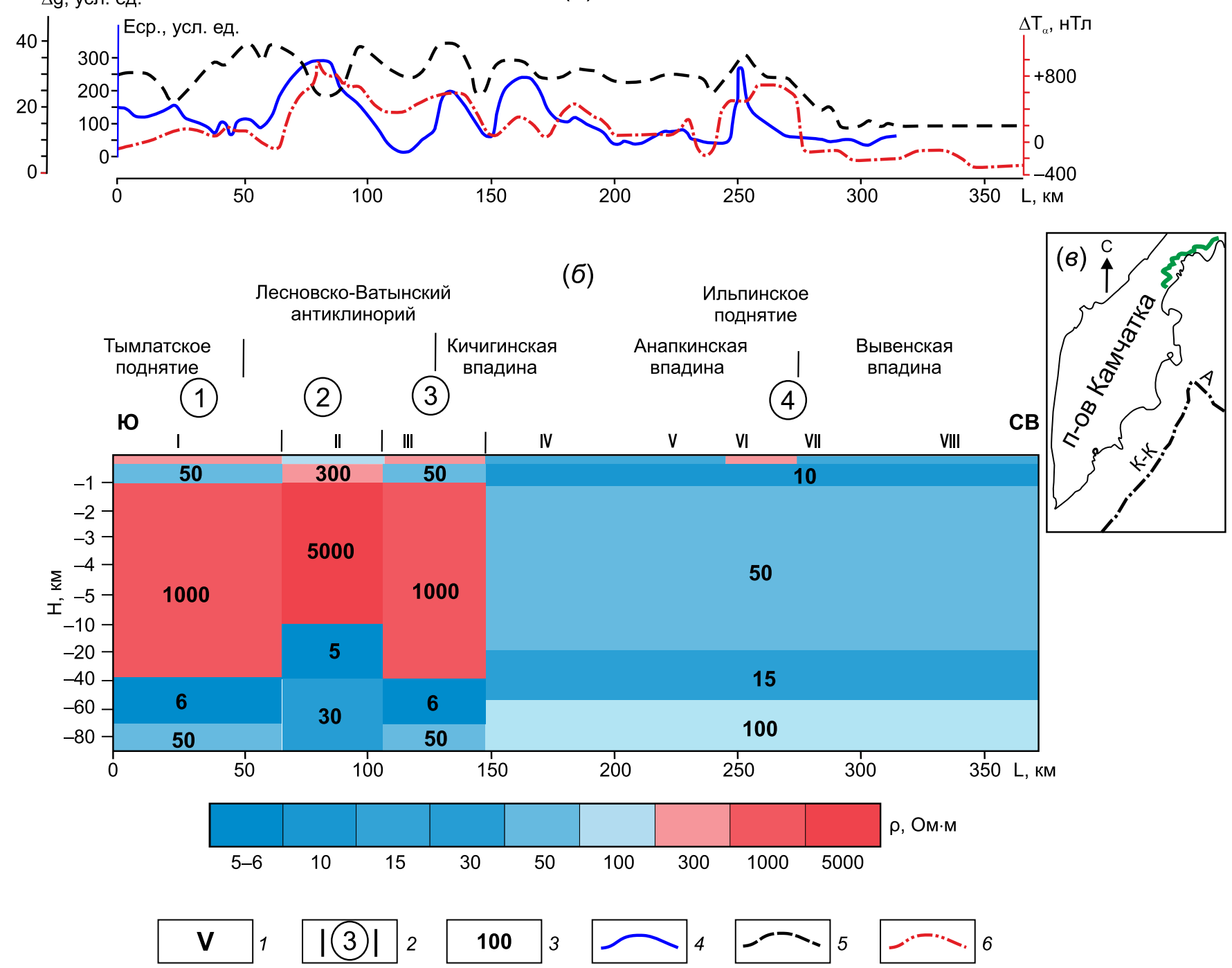

Рис. 5. Глубинный геоэлектрический разрез вдоль профиля «Северный» (б), приведенный в сопоставлении с графиками геофизических полей $(a)$.

1 - зоны, выделенные на первом этапе конформного осреднения кривых МТЗ; 2 - блоки, выделенные на втором этапе конформного осреднения кривых МТЗ; 3 - значения удельного электрического сопротивления в Ом·м; 4 - график средней напряженности теллурического поля [Мороз, 1976]; 5 - график поля силы тяжести [Декин, Зубин, 1976]; 6 - график аномального магнитного поля [Rivosh, 1963]. На вставке (в) зеленой линией показано расположение регионального профиля «Северный», черной линией показано положение осей глубоководных желобов (К-К - Курило-Камчатский, А - Алеутский) [Seliverstov, 2009].

Fig. 5. Deep geoelectrical section along the regional profile Severny (б), given in comparison with the magnetic anomaly and gravity curves $(a)$.

1 - zones identified at the first stage of conformal averaging of the MTS curves; 2 - blocks identified at the second stage of conformal averaging of the MTS curves; 3 - values of specific electrical resistance (Ohm·m); 4 - average telluric strength curve [Moroz, 1976]; 5 - gravity curve [Dekin, Zubin, 1976]; 7 - magnetic anomaly curve [Rivosh, 1963]. Inset (8): green line - regional profile Severny, black line - axes of deep-sea troughs (K-K - Kuril-Kamchatka, A - Aleutian) [Seliverstov, 2009].

сначала зонами трещиноватости, а затем (до глубин 30-35 км) - зонами раскрытия пор [Karakin et al., 1982; Lobkovsky et al., 1986]. Повышенный тепловой поток, как в южной, так и в северной части восточного побережья региона [Smirnov, Sugrobov, 1980], указывает на возможные процессы дегидратации пород, что приводит к появлению водных растворов, понижающих удельное электрическое сопротивление в разрезе [Ravich, 1971]. Таким образом, при интерпретации экспериментальных данных МТЗ высокие значения параметра сопротивления, достигающие сотен - тысяч Ом·м, связываются нами с твердым агрегатным состоянием вещества. А низкоомные зоны, характеризующиеся 
значениями от первых единиц до первых десятков Ом•м, мы соотносим с насыщением пород высокоминерализованными флюидами.

Сопоставление полученных геоэлектрических разрезов позволяет говорить о их принципиально разном строении. Согласно работе [Mishin et al., 2003], северно-восточный район расположен в краевой западной (северо-западной) части палеосубокеанической плиты, где в высокой степени проявился региональный метаморфизм, вследствие чего верхняя часть разреза северо-восточного побережья характеризуется меньшими значениями удельного электрического сопротивления по сравнению с юго-восточным районом с развитыми высокоомными вулканогенными образованиями. Также изменение параметра сопротивления вдоль юго-восточного побережья Камчатки происходит резко, отображая блочное строение этого участка в виде чередования областей высокой и низкой электропроводности. Однако в целом наблюдается тенденция понижения удельного электрического сопротивления в юго-восточном направлении при приближении профиля к акватории.

Вызывает большой интерес расположение литосферного проводящего слоя в разрезах восточного побережья. В юго-восточной части Камчатки такой слой залегает на меньших глубинах, чем на северовостоке. Максимальное погружение кровли проводящего горизонта на юге восточного побережья достигает 30 км, а на севере - 40 км. К тому же удельное электрическое сопротивление такого горизонта гораздо ниже в северной части, чем в южной.

\section{6. ЗАКЛЮЧЕНИЕ}

Глубинная электропроводность восточного побережья Северной и Южной Камчатки изучена с помощью МТЗ, выполненного вдоль региональных профилей «Северный» и «Южный». С применением численного трехмерного моделирования магнитотеллурического поля Камчатки разработаны глубинные геоэлектрические модели, демонстрирующие распределение областей высоких и низких значений удельного электрического сопротивления. Высокоомные блоки связываются с насыщенностью разреза магматическими породами. Блоки с относительно повышенной электропроводностью можно объяснить преобладанием в разрезе терригенных толщ или повышенной пористостью вулканогенных пород, заполненной высокоминерализованными растворами.

\section{7. БЛАГОДАРНОСТИ}

Полевые исследования выполнены ОАО «Камчатгеология» с участием 000 «Северо-Запад» (г. Москва) в соответствии с Государственным контрактом, заключенным в 2007 г. между Управлением по недропользованию по Камчатской области («Камчатнедра») и ОАО «Камчатгеология». Авторы выражают благодарность 000 «Северо-Запад» и OAO «Камчатгеология» за предоставленные данные МТЗ. Работа выполнена при финансовой поддержке РФФИ по проектам № 16-35-00088, 16-0500059.

\section{8. ЛИТЕРАTУРA / REFERENCES}

Aprelkov S.E., 1971. Tectonics and the history of volcanism of Southern Kamchatka. Geotectonics (2), 47-61 (in Russian) [Апрелков С.E. Тектоника и история вулканизма Южной Камчатки // Геотектоника. 1971. № 2. С. 47-61].

Aprelkov S.E., Podpruzhenko S.V., 2009. The Penzhina-West Kamchatka folded zone and the Ukelayat-Sredinnyi block in the structure of the Koryak Highland and Kamchatka. Russian Journal of Pacific Geology 3 (4), 388-400. https:// doi.org/10.1134/S181971400904006X.

Belousov V.V. (Ed.), 1987. Essays on Tectonic Development of Kamchatka. Nauka, Moscow, 248 p. (in Russian) [Очерки тектонического развития Камчатки / Ред. В.В. Белоусов. М.: Наука, 1987. 248 с.].

Belyavksii V.V., Aleksanova E.D., 2014. Three-dimensional geoelectrical model of southern Kamchatka. Izvestiya, Physics of the Solid Earth 50 (1), 9-31. https://doi.org/10.1134/S1069351314010029.

Belyavksii V.V., Zolotov E.E., Nurmukhamedov A.G., Rakitov V.A., Shpak I.P., Khrapov A.V., Yakovlev A.G., 2008. Seismogeoelectrical model of the Okhotsk-Chukotka volcanogenic belt and the Central Koryak folded zone along the profile Verkhnee Penzhino - Korf. Geofizika (Geophysics) (2), 30-44 (in Russian) [Белявский В.В., Золотов E.E., Нурмухамедов А.Г., Ракитов В.А., Шпак И.П., Храпов А.В., Яковлев А.Г. Сейсмогеоэлектрическая модель Охотско-Чукотского вулканогенного пояса и Центрально-Корякской складчатой зоны по профилю Верхнее Пенжино - Корф // Геофизика. 2008. № 2. С. 30-44].

Dekin G.P., Zubin M.I., 1976. The relief of fundamental surfaces of Kamchatka Earth crust boundaries. In: M.L. Krasnyi, Yu.A. Pavlov (Eds.), Geophysical fields of the Northwestern Part of the Pacific Mobile Belt. FESC AS USSR, Vladivostok, p. 44-55 (in Russian) [Декин Г.П., Зубин М.И. Рельеф основных поверхностей раздела земной коры Камчатки // Геофизические поля северо-запада Тихоокеанского подвижного пояса / Ред. М.Л. Красный, Ю.А. Павлов. Владивосток: ДВНЦ АН СССР, 1976. С. 44-55]. 
Geology of the USSR, 1964. Vol. 31. Kamchatka, the Kurile Islands and the Commander Islands. Geological Description. Nedra, Moscow, 733 p. (in Russian) [Геология СССР. Т. 31. Камчатка, Курильские и Командорские острова. Геологическое описание. М.: Недра, 1964. 733 с.].

Gontovaya L.I., Popruzhenko S.V., Nizkous I.V., 2010. Upper mantle structure in the ocean-continent transition zone: Kamchatka. Journal of Volcanology and Seismology 4 (4), 232-247. https://doi.org/10.1134/S0742046310040 020.

Karakin A.V., Lobkovsky L.I., Nikolaevsky V.N., 1982. Formation of the serpentinite layer of the oceanic crust and some geological and geophysical phenomena. Doklady AN SSSR 265 (3), 572-576 (in Russian) [Каракин А.В., Лобковский Л.И., Николаевский В.Н. Образование серпентинитового слоя океанической коры и некоторые геолого-геофизические явления // Доклады АН СССР. 1982. Т. 265. № 3. С. 572-576].

Krasny L.I. (Ed.), 1966. Geological Structure of the Northwestern Part of the Pacific Mobile Belt. Nedra, Moscow, 516 p. (in Russian) [Геологическое строение северо-западной части Тихоокеанского подвижного пояса / Ред. Л.И. Красный. М.: Недра, 1966. 516 с.].

Litvinov A.F., Patoka M.G., Markovsky B.A. (Eds.), 1999. Mineral Map of the Kamchatka Region. Scale 1:500000. VSEGEI, St. Petersburg, Sheets VII, XI, and XIII (in Russian) [Карта полезных ископаемых Камчатской области. Масштаб 1:500000 / Ред. А.Ф. Литвинов, М.Г. Патока, Б.А. Марковский. СПб.: ВСЕГЕИ, 1999. Л. VII; Л. XI; Л. XIII].

Lobkovsky L.I., Nikolaevsky V.N., Karakin A.V., 1986. Geological and geophysical consequences of serpentinization of the oceanic lithosphere. Bulletin of Moscow Society of Naturalists, Geological Section 61 (4), 3-12 (in Russian) [Лобковский Л.И., Николаевский В.Н., Каракин А.В. Геолого-геофизические следствия серпентинизации океанической литосферы // Бюллетень Московского общества испытателей природы. Отдел геологический. 1986. Т. 61. Вып. 4. С. 3-12].

Mackie K.L., Smith J.T., Madden T.R., 1994. Three-dimensional electromagnetic modeling using finite difference equations: the magnetotelluric example. Radio Science 29 (4), 923-935. https://doi.org/10.1029/94RS00326.

Mishin V.V., Nurmukhamedov A.G., Belousov S.P., 2003. Paleosubvolcanic type of the crust in the northeastern Kamchatka. Tikhookeanskaya Geologiya (Russian Journal of Pacific Geology) 22 (5), 58-72 (in Russian) [Мишин В.В., Нурмухамедов А.Г., Белоусов С.П. Палеосубвулканический тип земной коры на северо-востоке Камчатки // Тихоокеанская геология. 2003. Т. 22. № 5. С. 58-72].

Moroz Y.F., 1976. Results of East Kamchatka investigation by methods of geoelectrical prospecting - TC, MTS, VES Geologiya i Geofizika (Soviet Geology and Geophysics) (10), 140-144 (in Russian) [Мороз Ю.Ф. Результаты исследований восточной Камчатки комплексом методов электроразведки ТТ, МТЗ, ВЭЗ // Геология и геофизика. 1976. № 10. С. 140-144].

Moroz Y.F., Samoilova O.M., 2013. The deep structure of the Southern Kamchatka volcanic zone from geophysical data. Journal of Volcanology and Seismology 7 (2), 99-111. https://doi.org/10.1134/S074204631302005X.

Moroz Y.F., Samoilova O.M., 2017. Features of regional and local coast effects in magnetotelluric field of Kamchatka. Geofizicheskiye Issledovaniya (Geophysical Research) 18 (3), 81-94 (in Russian) [Мороз Ю.Ф., Самойлова О.М. Особенности регионального и локального береговых эффектов в магнитотеллурическом поле Камчатки // Геофизические исследования. 2017. Т. 18. № 3. С. 81-94]. https://doi.org/10.21455/gr2017.3-7.

Moroz Y.F., Samoilova O.M., Moroz T.A., 2015. Electric conductivity at depth: The southern coast of North Kamchatka. Journal of Volcanology and Seismology 9 (2), 125-139. https://doi.org/10.1134/S0742046315020062.

Nurmukhamedov A.G., 2003. Model of the geoelectrical section along the profile Lesnaya - Ossora according to the magnetotelluric sounding data (the Kamchatka Isthmus region) In: The First All-Russia School-Seminar on Electromagnetic Sounding of the Earth. MAKS Press, Moscow, p. 41 (in Russian) [Нурмухамедов А.Г. Модель геоэлектрического разреза по профилю п. Лесная - п. Оссора по данным магнитотеллурического зондирования (район Камчатского перешейка) // Первая Всероссийская школа-семинар по электромагнитным зондированиям Земли. М.: МАКС Пресс, 2003. С. 41].

Nurmukhamedov A.G., Chernev I.I., Alekseev D.A., Yakovlev A.G., 2010. 3D geoelectric model of the Mutnov steam hydrothermal deposit. Izvestiya, Physics of the Solid Earth 46 (9), 739-750. https://doi.org/10.1134/S106935131009 003X.

Nurmukhamedov A.G., Moroz Yu.F., 2008. Features of the geological structure of the northeastern part of the KoryakKamchatka folded area according to the data of deep geophysical studies. Bulletin of Kamchatka Regional Association Education-Science Centre. Earth Sciences (1), 125-133 (in Russian) [Нурмухамедов А.Г., Мороз Ю.Ф. Особенности геологического строения северо-восточной части Корякско-Камчатской складчатой области по данным глубинных геофизических исследований // Вестник КРАУНЦ. Серия Науки о Земле. 2008. № 1. C. 125-133].

Nurmukhamedov A.G., Moroz Yu.F., 2009. The deep structure of the northeastern part of the Koryak-Kamchatka folded region according to the data of regional geophysical studies. Geophysical Journal 31 (3), 1-10 (in Russian) [Нурмухамедов А.Г., Мороз Ю.Ф. Глубинное строение северо-восточной части Корякско-Камчатской складчатой области по данным региональных геофизических исследований // Геофизический журнал. 2009. Т. 31 . № 3. C. 1-10].

Ravich M.I., 1971. Phase equilibria in water-salt systems at elevated temperatures and pressures. In: V.V. Lapin (Ed.), Experimental modeling of natural processes. Nauka, Moscow, p. 112-118 (in Russian) [Равич М.И. Фазовые рав- 
новесия в некоторых водосолевых системах при повышенных температурах и давлениях // Экспериментальное моделирование природных процессов / Ред. В.В. Лапин. М.: Наука, 1971. С. 112-118].

Rivosh L.A., 1963. On tectonics of the Kamchatka Peninsula and the bottom of the adjacent marine areas (from the geophysical data). Geologiya i Geofizika (Soviet Geology and Geophysics) (6), 30-47 (in Russian) [Ривош Л.A. 0 тектонике Камчатского полуострова и дна прилегающих к нему морских районов (по геофизическим данным) // Геология и геофизика. 1963. № 6. С. 30-47].

Rivosh L.A., 1964. Geomagnetic characteristic of the main tectonic structures of the Soviet Union, the transition zone from the Asian Continent to the Pacific Ocean, and the abyssal bottom of the latter. Geologiya i Geofizika (Soviet Geology and Geophysics) (5), 38-51 (in Russian) [Ривош Л.A. Геомагнитная характеристика главных тектонических структур востока СССР, переходной зоны от Азиатского континента к Тихому океану и абиссального дна последнего // Геология и геофизика. 1964. № 5. С. 38-51].

Seliverstov N.I., 1998. The structure of the Bottom of the Maritime Areas near Kamchatka and the Geodynamics of the Junction Zone of the Kuril-Kamchatka and Aleutian Island Arcs. Nauchny Mir, Moscow, 164 p. (in Russian) [Селиверстов Н.И. Строение дна прикамчатских акваторий и геодинамика зоны сочленения КурилоКамчатской и Алеутской островных дуг. М.: Научный Мир, 1998. 164 с.].

Seliverstov N.I., 2009. Geodynamics of the Junction Zone of the Kuril-Kamchatka and Aleutian Island Arcs. Publishing House of Vitus Bering Kamchatka State University, Petropavlovsk-Kamchatsky, 191 p. (in Russian) [Селиверстов Н.И. Геодинамика зоны сочленения Курило-Камчатской и Алеутской островных дуг. ПетропавловскКамчатский: Издательство КамГУ им. Витуса Беринга, 2009. 191 с.].

Smirnov L.M., 1971. Tectonics of the Western Kamchatka. Geotektonika (Geotectonics) (3), 104-118 (in Russian) [Смирнов Л.М. Тектоника Западной Камчатки // Геотектоника. 1971. № 3. С. 104-118].

Smirnov Ya.B., Sugrobov V.M., 1980. Earth heat flux in the Kuril-Kamchatka and Aleutian provinces. Vulkanologiya $i$ Seismologiya (Journal of Volcanology and Seismology) (1), 16-31 (in Russian) [Смирнов Я.Б., Сугробов В.М. Земной тепловой поток в Курило-Камчатской и Алеутской провинциях // Вулканология и сейсмология. 1980. № 1. C. 16-31].

Sobolev V.S. (Ed.), 1979. Problems of Deep Magmatism. Nauka, Moscow, 264 p. (in Russian) [Проблемы глубинного магматизма / Ред. В.С. Соболев. М.: Наука, 1979. 264 с.].

Van'yan L.L., 1977. Electromagnetic Sounding. Naychny Mir, Moscow, 219 p. (in Russian) [Ваньян Л.Л. Электромагнитные зондирования. М.: Научный мир, 1977. 219 с.].

Vlasov G.M., Yarmolyuk V.A., 1959. Structural-tectonic regions of Kamchatka. Doklady AN SSSR 127 (1), 156-158 (in Russian) [Власов Г.М., Ярмолюк В.А. Структурно-тектонические районы Камчатки // Доклады АН СССР. 1959. T. 127. № 1. С. 156-158].

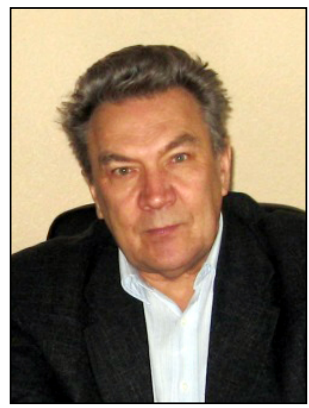

Юрий Федорович Мороз, докт. геол.-мин. наук, г.н.с.

Институт вулканологии и сейсмологии ДВО РАН

683006, Петропавловск-Камчатский, бульвар Пийпа, 9, Россия

Геологический институт СО РАН

670047, Улан-Удэ, ул. Сахьяновой, 6а, Россия

e-mail: morozyf@kscnet.ru

Yuri F. Moroz, Doctor of Geology and Mineralogy, Chief Researcher Institute of Volcanology and Seismology, Far East Branch of RAS

9 Piip Boulevard, Petropavlovsk-Kamchatsky 683006, Russia

Geological Institute, Siberian Branch of RAS

6a Sakhyanova street, Ulan-Ude 670047, Russia

e-mail: morozyf@kscnet.ru

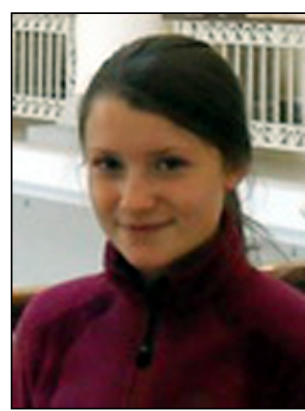

Ольга Михайловна Самойлова, н.с.

Институт вулканологии и сейсмологии ДВО РАН

683006, Петропавловск-Камчатский, бульвар Пийпа, 9, Россия

凶e-mail: olgasm415@mail.ru

Olga M. Samoilova, researcher

Institute of Volcanology and Seismology, Far East Branch of RAS

9 Piip Boulevard, Petropavlovsk-Kamchatsky 683006, Russia

\e-mail: olgasm415@mail.ru 